\title{
Notas Críticas sobre a Nova Sociologia Econômica de Granovetter
}

\author{
Paulo Henrique Furtado de Araujo*
}

\begin{abstract}
Resumo: A nova sociologia econômica surge a partir da contribuição seminal de Mark Granovetter e se apresenta como reação ao imperialismo econômico que se dispõe a tratar de temas antes reservados a Sociologia, a Ciência Política e a Demografia. Sendo que o tal enfoque econômico é aquele propiciado pela teoria dominante no âmbito da Ciência Econômica, ou seja, a teoria das escolhas racionais. Cabe ressaltar que a nova sociologia econômica toma a nova economia institucional de Oliver Williamson como alvo de críticas, pois ainda que essa última tente explicar a constituição das instituições partindo de uma visão neoclássica reformada permanece enquanto uma visão subsocializada da ação humana. Granovetter identifica e critica o que ele entende ser o "outro lado da moeda" nessa questão da ação humana que é a visão sobressocializada. Tal visão se faz presente tanto na sociologia de Talcott Parsons quanto na teoria econômica dominante (Kenneth Arrow e Akerlof).
\end{abstract}

Palavras-chave: Nova Sociologia Econômica, Nova Economia Institucional, Escolhas Racionais.

Classificação JEL: B25, B52, B59, Z13.

\section{Critical Notes on Granovetter's New Economic Sociology}

\begin{abstract}
The new economic sociology arises from the seminal contribution of Mark Granovetter and appears as a reaction to the economic imperialism that has to deal with issues previously reserved Sociology, Political Science and Demography. Being that this economic approach is that afforded by the dominant theory in the framework of economic science, ie, the theory of rational choices. Importantly, the new economic sociology takes the new institutional economics of Oliver Williamson for criticism, because although the latter try to explain the formation of institutions starting from a reformed neoclassical vision remains undersocialized while a view of human action. Granovetter identifies and criticizes what he considers to be the "flip side" of human action in this matter is that the sobressocializada vision. Such a view is present in both the sociology of Talcott Parsons as the dominant economic theory (Akerlof and Kenneth Arrow).
\end{abstract}

Professor da Faculdade de Economia da UFF e membro do NIEP-MARX-UFF. E-mail: phfurtadoa@gmail.com 
Keywords: New Economic Sociology, New Institutional Economics, Rational Choice.

JEL Classification: B25, B52, B59, Z13.

\section{Introdução}

A nova sociologia econômica surge com força a partir da contribuição seminal de Mark Granovetter e se potencializa como reação ao imperialismo econômico que se dispõe a tratar de temas antes reservados a Sociologia, a Ciência Política e a Demografia. ${ }^{1}$ Sendo que o tal enfoque econômico é aquele propiciado pela teoria dominante no âmbito da Ciência Econômica, ou seja, a teoria das escolhas racionais. Cabe ressaltar que a nova sociologia econômica toma a nova economia institucional de Oliver Williamson como alvo de críticas, pois ainda que essa última tente explicar a constituição das instituições partindo de uma visão neoclássica reformada permanece enquanto uma visão subsocializada da ação humana. ${ }^{2}$ Granovetter (2003) identifica e critica o que ele entende ser o "outro lado da moeda" nessa questão da ação humana que é a visão sobressocializada. Tal visão se faz presente tanto na sociologia de Talcott Parsons quanto na teoria econômica dominante (Kenneth Arrow e Akerlof). Na visão subsocializada o agente econômico é entendido como capaz de tomar decisões estratégicas a cada momento de tal forma a sempre maximizar suas funções utilidade, logo estamos diante de um agente atomizado, para o qual as relações sociais têm pouca ou nenhuma importância nas suas tomadas de decisão maximizadora. Em suma, estamos dentro de um específico paradigma de racionalidade. Já a visão sobressocializada parece apontar para o agente como uma marionete cultural ${ }^{3}$, aqui "os padrões comportamentais são interiorizados, pelo que as relações sociais correntes têm apenas um efeito periférico sobre os comportamentos" (Granovetter, 2003, p. 73).

No momento cabe destacar que a nova sociologia econômica (doravante NSE) procura se constituir enquanto teoria capaz de dar uma explicação mais poderosa e, portanto, científica para os fenômenos mercantis do que a disponibilizada pela teoria econômica dominante. Para isso, ela vai utilizar-se de teorias alternativas as da teoria econômica para explicar a ação e racionalidade dos indivíduos reais e a constituição e reprodução das instituições. Ao ressaltarmos a importância da teoria da ação e das instituições, percebemos as afinidades entre a NSE e a antiga sociologia econômica de Durkheim e Weber para os quais os conceitos de ação e instituição tinham um papel central em suas construções teóricas. No presente trabalho,

Vide Steiner, 2006, p. 29.

2 Para ser mais preciso, cabe registrar que Granovetter (2003, p. 84) destaca que a análise de Willianson apresenta aspectos subsocializados e sobressocializados tais como os identificados no Leviathan de Hobbes.

3 Conforme Marques, 2003, p. 4. 
após apresentarmos de forma muito sucinta, as posições principais dos dois autores acima citados, vamos tratar (também de forma sucinta) do aporte de Karl Polanyi ao mesmo tema. Nesses três autores percebemos a tentativa de melhor articular a ações individuais e as grandes estruturas sociais no interior das quais essas ações são tomadas. Nossa ideia é identificar possíveis pontos de contato e potencialização da NSE a partir dos referidos autores, seguindo uma trilha já esboçada por autores como Steiner (2006), Swedberg (2004, 2005 e 2005b) e Raud-Mattedi (2005a e $2005 b)$. E encerramos com a exposição da postura crítica de Granovetter frente aos economistas modernos

\section{A velha sociologia econômica}

A sociologia enquanto campo do conhecimento remonta a Condorcet e ao iluminismo francês. Condorcet parece ser, "de todos os enciclopedistas” (Löwy, 1987, p. 19) o que mais contribuiu inicialmente para o surgimento da ideia de que era possível a identificação de leis naturais da vida social e a constituição de uma ciência da sociedade baseada no paradigma das ciências da natureza. Conhecedor dos trabalhos de Turgot (fisiocrata) e de Smith, acreditava que a "economia política pode estar submetida à "precisão do cálculo" e ao método das ciências da natureza." (idem) E generaliza esse entendimento para a totalidade dos fenômenos sociais, que estariam submetidos a leis similares às que operam na natureza. Leis constantes, gerais, necessárias e independentes da vontade do homem. A conclusão é da necessidade da constituição de uma "ciência natural da sociedade ou de uma 'matemática social' baseada no cálculo das probabilidades.” (idem) Ou seja, uma ciência neutra e isolada dos interesses e paixões inerentes aos pesquisadores e aos homens em geral. Ressalte-se que a construção teórica de Condorcet situa-se no âmbito da luta para desvencilhar o conhecimento social dos interesses das classes dominantes de sua época, livre de preconceitos, bem entendido: a igreja e suas doutrinas teológicas e dogmas que sustentavam ideologicamente todo o edifício social da sociedade feudal.

Saint-Simon, que foi discípulo de Condorcet, compartilha com seu mestre a ideia de que a ciência do homem deve ser constituída como um ramo da física ou da fisiologia, ou seja, deve utilizar os métodos das ciências naturais e assim tornar-se uma ciência positiva. ${ }^{4}$ Ele pretendeu constituir uma ciência da sociedade tendo por base o modelo biológico, daí designar como fisiologia social a sua nova ciência da sociedade. Tal proposta, mais ainda do que em Condorcet, deve ser vista a partir do quadro de luta empreendida por um socialista utópico contra as doutrinas das classes dominantes do período. Pois através dela comprova-se que "certas classes sociais são parasitas do organismo social” (Löwy, 1985, p. 38 e Löwy, 1987, p. 21).

Com August Comte temos uma modificação fascinante na visão de mundo positivista. Comte fora discípulo de Saint-Simon, mas guardava em relação a esse e

\footnotetext{
${ }_{4}$ Segundo Löwy (1985, p. 38 e 1987, p. 20) ele é o primeiro a usar este termo positivo.
} 
a Condorcet uma diferença fundamental: ele acreditava que o pensamento deveria ser totalmente positivo, isto é, deveria abandonar o viés crítico, a negatividade, os aspectos revolucionários do pensamento. Para ele Saint-Simon não conseguira descobrir as leis sociológicas por que seus preconceitos revolucionários o impediam. Reparemos como a noção de preconceito é agora utilizada de forma diferente do que já fora por Condorcet e Saint-Simon. Com estes o preconceito designa o preconceito das classes dominantes, clerical, absolutista, etc, com Comte passa a designar os preconceitos revolucionários. Daí a afirmação de Comte de que "seu método positivo deve consagrar teórica e praticamente à defesa da ordem real”. (Löwy, 1985, p. 39) ${ }^{5}$. Apesar disso, Comte vai utilizar o mesmo princípio metodológico de Condorcet e Saint-Simon que é o de uma ciência natural da sociedade. E assim, defender a existência de uma homogeneidade epistemológica entre as ciências sociais e naturais, de forma a mostrar uma identidade entre sociedade e natureza, e uma dominação da vida social por leis naturais invariáveis. Em resumo:

"Enquanto ciência natural da sociedade, a física social - mais tarde qualificada pelo neologismo sociologia - não pode ser senão tão neutra e livre de julgamentos de valor quanto a astronomia e a química (...). De fato, o discurso positivista pode (e deve) fazer economia de todo posicionamento ético ou político sobre o estado de coisas existente: 'sem admirá-lo', ele se limita a constatar que este estado é natural, necessário, inevitável, e é produto de 'leis invariáveis”' (Löwy, 1987, p. 24)

O termo sociologia foi criado por Comte, mas é Durkheim quem a transforma em disciplina científica. E existe uma continuidade clara entre as metodologias utilizadas pelos dois. Ambos consideram os fatos sociais como coisas, Comte defendia que os fatos sociais devem ser considerados como fatos naturais submetidos a leis naturais, Durkheim concorda com tal formulação e defende que as leis sociais são semelhantes às leis naturais e os métodos que devem ser utilizados para a descoberta das leis sociais são os mesmos utilizados para as leis naturais. Ressalte-se que tal perspectiva está presente na economia política de então e segundo Durkheim: "Os economistas foram os primeiros a proclamar que as leis sociais são tão necessárias como as leis físicas. Segundo eles, é tão impossível a concorrência não nivelar pouco a pouco os preços... como os corpos não caírem de forma vertical... Estenda este princípio a todos os fatos sociais e a sociologia estará fundada." (Durkheim, La Science et l'Action, PUF, Paris, 1970, p. 80-81; Apud, Löwy, 1987, p. 26)

Todo esse constructo revela as bases de um naturalismo positivista associado à origem da própria sociologia. E este conceito que fora utilizado como instrumento revolucionário pelos ideólogos de 1789, agora é convertido numa "justificação científica da ordem social estabelecida”. (Löwy, 1987, p. 27) Pois, segundo Durkheim a vontade humana não pode interromper, modificar uma lei natural. Por exemplo, seria utópico querer alterar a desigualdade social. Na perspectiva de associar a construção do conhecimento com o ponto de vista de classe social do pesquisador (algo

\footnotetext{
5 Ver essa discussão também em Löwy, 1978, p. 9-11 e 1987, p. 22-25.
} 
refutado pelo positivismo que Durkheim alimenta), a burguesia (nas suas várias frações constitutivas) já perdera o seu papel revolucionário que tivera nas jornadas de 1789. Agora ela esforça-se para manter o status quo vigente. ${ }^{6}$

Durkheim acredita que haja uma homogeneidade no âmbito da teoria do conhecimento entre o ser natural e o ser social, logo conclui sobre a necessidade do sociólogo se colocar diante do seu objeto de estudo, da mesma forma que o fazem o físico, o químico, etc. De forma neutra, abrindo mão de seus preconceitos e prenoções. Assinale-se que tal procedimento vai se tornar uma exigência fundamental para todas as correntes positivistas. ${ }^{7}$ Assim, desconhece-se as características constitutivas da ciência social em relação a ciência natural, cujas causas são:

1. O caráter histórico dos fenômenos sociais, transitórios, perecíveis, suscetíveis de transformação pela ação dos homens. 2. A identidade parcial entre o sujeito e o objeto do conhecimento. 3. O fato de que os problemas sociais suscitam a entrada em jogos de concepções antagônicas das diferentes classes sociais. 4. As implicações político-ideológicas da teoria social: o conhecimento da verdade pode ter conseqüências diretas sobre a luta de classes. (LÖWY, 1978, p. 15)

O mais importante para o presente trabalho é demonstrar que Durkheim constrói uma proposta de análise da economia que se põe como alternativa à proposta da economia neoclássica de ver as relações econômicas (de mercado) como desenraizadas das relações sociais em geral, para ele o mercado deve ser visto como construção social. Neste ponto é importante frisar que a abordagem dele se situa na esfera do mercado, o que Marx situa como a aparência do ser social com todas as conseqüências de perda de poder explicativo que se incorre ao ficar preso à esfera da aparência. O que, aliás, é típico também da economia neoclássica que Marx dizia ser a economia vulgar em contraposição à economia científica de Smith, Ricardo, etc. Segundo Cécile Raud-Mattedi (2005a) temos que Durkheim não define o que é o mercado, considerando-o como uma instituição, um fato social. E no cerne do mercado encontra-se a noção de contrato, e a sociedade moderna por ser uma sociedade de mercado é também uma sociedade contratual. Em Durkheim a troca mercantil que ocorre no quadro da divisão social do trabalho tem um papel socializador, pois a

6 Esta perspectiva tão bem delineada por Löwy nos textos citados, poderia ser proveitosa para Giddens (1998, p. 119) desenvolver seu argumento de que "é errôneo considerá-lo [Durkheim] primordialmente conservador no seu ponto de vista intelectual”. Pois o que Giddens aponta é para a necessidade sentida por Durkheim de conservar os avanços já obtidos pela burguesia industrial e continuar as transformações socioeconômicas necessárias para consolidar a nova ordem industrial. Neste sentido ele é duplamente conservador e revolucionário, mas isso não elimina seu compromisso intelectual-teórico com a sociedade fundada sobre a lógica do capital.

7 Conforme Löwy, 1987, p. 29. 
(...) coesão social no âmbito da solidariedade orgânica nasce das interdependências decorrentes da especialização e da divisão social do trabalho. A sociedade moderna prescinde da forte consciência coletiva, que assegura a coesão social nas sociedades tradicionais, onde não há divisão do trabalho [sic]. Portanto, a relação mercantil, que obriga pessoas a entrar no mercado para trocar bens e serviços indispensáveis à sua sobrevivência, encerra uma dimensão socializadora. No entanto, isto não ocorre espontaneamente, como pretendem Spencer e os economistas liberais. Portanto, a ordem social não decorre da busca egoísta de seu interesse por parte de cada indivíduo isolado. 'Para que cooperem harmoniosamente [...] é necessário [...] que as condições dessa cooperação sejam estabelecidas para toda a duração de suas relações', e isto será feito por regras formais (jurídicas) e/ou informais (tradição, normas) (DURKHEIM, 1995, p.200, apud. RAUD-MATTEDI, 2005a, p. 129)

Aqui já se percebe a importância que Durkheim atribui ao direito contratual e as regras informais na regulação do mercado. Mas a partir dessa perspectiva ele aponta que o mercado como pensado pelos economistas neoclássicos resultaria num tipo de solidariedade precária, pois fundada numa solidariedade inconstante, superficial e conflituosa. A verdadeira relação social, na sociedade baseada divisão social do trabalho só se constitui quando o agente econômico assume e se insere num conjunto de regras sociais (de direito, norma ou tradição) elaboradas coletivamente, ou seja, quando ele se insere numa relação contratual. Assim conclui Raud-Mattedi: “(...) a relação mercantil gera um laço social mesmo sem passar por relações pessoais íntimas, na medida em que esse laço não se esgota no único traço da troca, mas se enraíza e participa do processo de reprodução das instituições sociais" (2005a, p. 129). Raud-Mattedi retomando Chantelat sinaliza que tal perspectiva aberta por Durkheim pode ajudar o limite aparentemente presente na nova sociologia econômica de assumir uma visão intimista do laço social constitutivo do mercado. Com Durkheim ficaria claro que na sociedade moderna não é fundamental a consciência orgânica dos seus membros como ocorria nas sociedades tradicionais. Agora a coesão social é devida à interdependência originada pela divisão social do trabalho.

Ainda sobre o enfoque de Durkheim é preciso lembrar o papel das instituições (no que ele antecipa em alguns aspectos a problemática da nova economia institucional) e das representações sociais na explicação do comportamento econômico. Daí diz Steiner:

Isto leva os durkheimianos a interessar-se pela imbricação estreita existente entre os comportamentos egoístas e os comportamentos baseados em normas sociais (por exemplo: a justiça nos contratos ou a fixação dos salários) ou em estruturas cognitivas (por exemplo, a representação do comerciante ou dos proprietários de imóveis na classe operária), já que ambas ditam elementos que são indispensáveis na análise das ocorrências sociais observadas (a multiplicidade crescente das trocas, o rendimentos do trabalho, a estrutura dos orçamentos operários e sua evolução). (STEINER, 2006, p. 11) 
Aqui entramos no âmbito das teorias da ação que têm em Weber uma tipologia muito conhecida e utilizada ainda hoje. Mas antes de tratarmos desta tipologia e das contribuições da sua sociologia econômica, vejamos como Weber tenta se dissociar, sem conseguir de fato, da sociologia positivista que teve em Durkheim um momento importante.

Weber não é um autor positivista stricto sensu, teve divergências com o pensamento positivista, mas ele tem um ponto de convergência com o positivismo ao defender que a ciência social deve ser livre dos juízos de valor. Para entender um pouco melhor tal questão é preciso lembrar que Weber foi aluno de Rickert ${ }^{8}$ e este último propôs uma crítica forte às ideias positivistas ao dissociar os métodos das ciências naturais do método das ciências sociais-históricas. Rickert entendia que o estudo nas ciências sociais-históricas deveria necessariamente partir de certos valores prévios. Mas enquanto ele acreditava em valores universais, Weber negava essa possibilidade e defendia que cada nação, cada cultura, cada religião tem valores particulares e diferentes. De todo modo, para ambos (e ao contrário do que propunha Durkheim) os valores, as prenoções, não devem ser eliminados. Na verdade eles são indispensáveis no âmbito das ciências sociais para a delimitação do objeto de estudo, para a orientação da pesquisa, para a definição do que é essencial, dos instrumentais a serem utilizados, etc. Os valores vão permitir a formulação das perguntas a serem feitas sobre o objeto de estudo. Assim, quando trata da formulação do objeto da pesquisa, Weber constrói toda uma crítica aos postulados positivistas. Entretanto, quando parte para resposta, para as conclusões da pesquisa ele volta ao positivismo. Pois defende que o método de pesquisa deve seguir normas universalmente aceitas, objetivas, neutras, independentes dos valores, válidas para quaisquer pesquisadores independentemente dos seus valores, nacionalidades, religiões, etc. ${ }^{9}$ Há uma tensão no pensamento de Weber entre uma tendência historicista presente ao aceitar os valores como fundamentais para a delimitação do objeto de estudo e uma tendência positivista de entender que o método da pesquisa deve prescindir dos valores.

Cabe registrar que enquanto Weber defende uma separação lógica entre valores e fatos ${ }^{10}$, existe uma ligação entre eles que vai além da lógica, uma ligação que é sociológica e conforme Löwy se manifesta em dois sentidos:

1. O conhecimento (ou a ignorância) dos fatos, da verdade objetiva, pode ter uma influência poderosa sobre as opções práticas, ética, sociais ou políticas de certos grupos

Conforme Löwy, 1985, p. 45-55 e Löwy, 1987, p. 33-47.

9 Löwy (1985, p. 50-51) aponta que Weber acredita que o processo de construção do conhecimento pode estar livre do julgamento de valor por relacionar os valores às culturas nacional e religiosa, não relacionando às classes sociais.

10 Para ele não se pode deduzir os fatos a partir dos valores, pois os valores podem inspirar a questão que vai ser estudada mas não pode ser o ponto de partida de uma análise científica. Tampouco se pode deduzir os valores dos fatos, ou seja, da análise científica não podemos retirar juízos morais, padrões éticos, etc. 
ou camadas sociais. Por exemplo: a crença em que o aumento do salário seja a causa principal da inflação pode ter um efeito paralisante sobre a atividade reivindicatória dos operários, sua atitude face às greves, etc.

2. Os julgamentos de valor, os pontos de vista de classe, as ideologias, utopias e visões de mundo dos grupos sociais influenciam de forma decisiva - direta ou indireta, consciente ou não - o conjunto da atividade científica e cognitiva no domínio das ciências sociais. Isto é, tanto a problemática como a pesquisa empírica dos fatos e de sua causalidade, assim como sua interpretação social e histórica de conjunto (LÖWY, 1987, p. 40).

A escolha por parte do pesquisador do que é a problemática a ser estudada e nela do que é ou não essencial define um campo de visibilidade e de não-visibilidade, e impõe os limites para as possíveis respostas a que se chegará. Weber era por demais inteligente para não reconhecer este fato ${ }^{11}$, mas o remédio assinalado para este problema que ameaçava todos os seus pressupostos teóricos era o do autocontrole da parte do pesquisador para impedir a contaminação de sua pesquisa por seus valores, preconceitos e prenoções.

Tratando agora da sociologia econômica de Weber cabe mencionar que ela busca explicar fenômenos econômicos (instituições econômicas como mercado e empresa), fenômenos não econômicos que influenciam os fenômenos econômicos (fenômenos economicamente relevante) e fenômenos não econômicos influenciados pelos fenômenos econômicos (fenômenos economicamente condicionados). Segundo Swedberg (2005b, p. 288) um exemplo dos primeiros tipos de fenômenos é obtido em A Ética Protestante e o Espírito do Capitalismo na tese de que o protestantismo ajudou a dar forma à mentalidade capitalista moderna. O fenômeno economicamente condicionado "seria a localização de agentes em diferentes classes e estratos, a qual influencia as crenças religiosas". (idem) Weber se propõe a introduzir a estrutura social na análise econômica partindo da ação individual. Esta ação é motivada por interesses e se orienta pela utilidade e para o comportamento dos outros agentes. Aqui o hábito e as emoções influenciam a ação social. $\mathrm{Na}$ sua tipologia da ação social exposta no capítulo 1 de Economia e Sociedade, Weber fala de quatro tipos principais ${ }^{12}$ : ação social tradicional que é movida pelo hábito ou tradição; ação social afetiva, movida pelas emoções; ação social racional com relações a valores movida por interesses ideais e ação racional com relação a fins (instrumental racional) que é movida por interesses materiais.

No capítulo 2 do mesmo livro Weber fala de ação econômica que tem um escopo mais limitado a um tipo de atividade quando comparado com o conceito de ação social. No primeiro parágrafo deste capítulo ele diz: "Uma ação será denominada 'economicamente orientada' na medida em que, segundo seu sentido visado, esteja referida a cuidados de satisfazer o desejo de obter certas utilidades" (Weber,

11 Conforme Löwy, 1987, p. 42, encontramos em Théorie de la science, p. 126.

12 Vide Swedberg, 2005b, p. 47 Steiner, 2006, p. 23. 
1999, p. 37) Repare que o conceito de utilidade em Weber, conforme Swedberg (2005b, p. 53), diz respeito tanto a mercadorias (objetos) quanto a serviços. E Swedberg destaca três dimensões no conceito de utilidade de Weber: 1) o importante não é a qualidade inerente ao objeto, mas o uso que se faz dele; 2) o conceito de utilidade como base da ação econômica, inclui a geração de lucro; 3 ) enfatiza a oportunidade econômica e as incertezas associadas na ação econômica.

Nesse mesmo capítulo 2, Weber discute diferentes tipos de ação social econômica. A primeira distinção é a que separa a economia doméstica da geração de lucros. Em seguida ele apresenta outras tipologias que vão instrumentalizar a distinção entre economia doméstica e geração de lucro: $1^{\circ}$.) A ação econômica pode ser racional ou tradicional, e esta se aplica tanto a economia doméstica quanto a geração de lucros. Sendo que o tradicional está associado ao comportamento da unidade familiar tradicional, o oikos (unidade econômica comum na Grécia antiga, voltada para a subsistência e para o atendimento das necessidades do senhor do oikos e dos que o cercavam), a manufatura tradicional e às formas obsoletas de ganhar dinheiro. Já a racional associa-se à família moderna, a atividade bancária moderna e a empresa moderna. $2^{\circ}$.) Distingue entre 'ação econômica' e ação economicamente orientada'. Ação economicamente orientada engloba “ (...) as ações que não são primariamente orientadas pelas ações econômicas, mas que ainda assim, levam em conta considerações econômicas; e em segundo lugar, as ações que são diretamente orientadas por objetivos econômicos, mas que usam a violência para alcançá-los” (Swedberg, 2005, p. 57). Weber também introduz alguns conceitos para tratar das lutas na economia. "Um deles é o 'poder de controlar e dispor', que é semelhante ao poder econômico” (idem, p. 58). Assim, Swedberg alinhava três elementos, que segundo ele, caracterizam o conceito de ação econômica: “(1) há uma tentativa pacífica de obter o poder de controlar e dispor; 2) essa ação é dirigida para algo que oferece uma oportunidade de utilidade (seja para satisfazer as próprias necessidades, seja para obter lucros); e 3 ) a ação é orientada pelo comportamento dos outros.” (ibid.)

Nos capítulos 1, 2 e 3 da Primeira Parte do Volume 1 de "Economia e Sociedade”, Weber apresenta alguns conceitos importantes para a discussão sobre a estrutura econômica, conforme nos lembra Swedberg (2005). Vamos apontar alguns desses conceitos aqui, acompanhando os destaques de Swedberg. De início destacamos o conceito de "regularidades determinadas pelo interesse", pois Weber identifica que regularidades de ação social determinadas por interesses individuais “(...) tendem a se transformar em formas regulares de comportamento coletivo que são muito comuns na economia." (2005, p. 58) O comportamento dos preços é um bom exemplo deste caso, pois os agentes individuais não são coagidos a fazer as mesmas escolhas, mas ao seguirem seus interesses particulares suas ações tornam-se similares.

Os conceitos de relações "comunais" e "associativas” nos põe em contato com o conceito de enraizamento de Mark Granovetter. Relações “comunais” “(...) implicam um sentimento de fazer parte de um mesmo conjunto, ao passo que as relações associativas dizem respeito a um acordo racional, que caracteristicamente 
envolve interesses" (p. 59). Logo, ações econômicas são associativas, sendo o mercado um dos casos mais puros. Pois compradores e vendedores entram em contato por parcos instantes e podem não mais se reencontrar. Mas Weber destaca que mesmo nas relações "associativas" existe um sentimento de pertencimento a um grupo.

O poder é algo presente e importante na construção teórica de Weber, principalmente se considerarmos as relações interconectadas de luta, concorrência e seleção e o de dominação. Weber no oitavo parágrafo do capítulo 1 de "Estado e Sociedade" diz que

Uma relação social denomina-se luta quando as ações se orientam pelo propósito de impor a própria vontade contra a resistência do ou dos parceiros. Denominamos 'pacíficos' aqueles meios de luta que não consistem em violência física efetiva. A luta pacífica é 'concorrência' quando se trata da pretensão formalmente pacífica de obter para si o poder de disposição sobre oportunidades desejadas também por outras pessoas. Há 'concorrência regulada', na medida em que esta, em seus fins e meios, se orienta por uma ordem. À luta (latente) pela existência, isto é, pelas possibilidades de viver ou de sobreviver, que se dá entre indivíduos ou tipos humanos sem que haja intenções dirigidas contra outros, denominamos 'seleção': 'seleção social' quando se trata das possibilidades que pessoas concretas têm na vida; 'seleção biológica' quando se trata das probabilidades de sobrevivência do patrimônio genético (WEBER, 1999, p. 23-24).

Sobre poder e dominação ele diz, no décimo sexto parágrafo do capítulo 1 da mesma obra que:

Poder significa toda a probabilidade de impor a própria vontade numa relação social, mesmo contra resistências, seja qual for o fundamento dessa probabilidade.

Dominação é a probabilidade de encontrar obediência a uma ordem de determinado conteúdo, entre determinadas pessoas indicáveis; disciplina é a probabilidade de encontrar obediência pronta, automática e esquemática a uma ordem, entre uma pluralidade indicável de pessoas, em virtude de atividades treinadas (ibid., p. 33).

O capítulo 3 de "Economia e sociedade" intitula-se "Os tipos de dominação", nele Weber defende que todo sistema político funda-se numa forma de dominação. A economia por fazer parte do sistema político acaba tendo o seu funcionamento submetido a este tipo de dominação política. No capitalismo moderno o Estado coloca os limites para o funcionamento da economia, nas sociedades antigas a organização política dominante tinha uma relação de dominação direta sobre a economia. Segundo Swedberg (2005, p. 60) no âmbito da economia temos relações de dominação, daí ele chamar “(...) esse tipo de dominação caracterizado, em primeiro lugar e principalmente, pelas relações no seio das organizações econômicas, de dominação econômica (em contraposição à dominação política). Uma das condições do capitalismo de racionalidade máxima, por, exemplo, é exatamente a de que as 
organizações econômicas sejam estruturadas como 'sistemas de dominação"”. Mas para Weber a dominação não está presente no mercado, ainda que existam agentes em posição vantajosa por terem poder de controlar e dispor das mercadorias.

Os conceitos de "relações fechadas" e "relações abertas" são muito importantes para a sociologia econômica de Weber, daí ser necessário retomá-los aqui. Ele as define no parágrafo 10 do capítulo 1 de "Economia e Sociedade", vejamos:

Uma relação social (...) será designada aberta para fora, quando e na medida em que a participação naquela ação recíproca, que a constitui segundo o conteúdo de seu sentido, não é negada, por sua ordem vigente, a ninguém que efetivamente esteja em condições e disposto a tomar parte nela. Ao contrário, é chamada fechada para fora quando e na medida em que o conteúdo de seu sentido ou sua ordem vigente exclui, limita ou liga a participação a determinadas condições (WEBER, 1999, p. 27).

Essas relações abertas e fechadas dominam a economia e estão relacionadas às tentativas feitas pelos agentes econômicos de se apropriarem e obterem, se possível, o monopólio das oportunidades econômicas. Quando a expectativa por parte dos agentes econômicos estabelecidos é de que a entrada de novos agentes melhore a posição individual dele, ele se movimentará para manter as relações abertas; caso contrário vai se movimentar por relações fechadas. Como exemplos, podemos lembrar dos cartéis, monopólios, mercado interno de trabalho, etc.

O conceito de racionalidade e de ação econômica racional também tem um papel importante na sociologia econômica de Weber. Segundo Swedberg “(...) [Para Weber] uma das tarefas da sociologia econômica é estudar a evolução do comportamento econômico racional para a 'racionalidade econômica' (...) como parte de um movimento histórico mais amplo.” (2005, p. 62) Mas em dois aspectos a racionalidade econômica de Weber se separa da racionalidade econômica proposta pela teoria econômica neoclássica. Weber entende o comportamento racional como algo que evolui historicamente, como uma variável e não um pressuposto, um axioma (como faz a teoria neoclássica). E Weber distingue entre "racionalidade formal" e "racionalidade substantiva". A formal situa-se em torno do cálculo e a substantiva opera com valores absolutos. A teoria neoclássica até tenta tirar conclusões éticas partindo do conceito de ótimo de Pareto, mas Weber trata da relação entre economia e ética por outro caminho e mostra que a ação orientada pelo valor com racionalidade substantiva pode ser tão racional quanto a lógica econômica formal.

Swedberg (2005) assinala que Weber não usa o termo "instituição" ou "instituição econômica” ${ }^{13}$, entretanto, ao iniciar sua análise a partir dos vários tipos de

${ }_{13} \mathrm{Na}$ edição brasileira o parágrafo 15 do primeiro capítulo intitula-se "Empresa e associação de empresa, união e instituição”. E diz que “(...) instituição [é] uma associação cuja ordem estatuída se impõe, com (relativa) eficácia, a toda ação com determinadas características que tenha lugar dentro de determinado âmbito de vigência”. (1999, p. 32) Seria o caso de se examinar o texto no original em alemão para dirimir essa questão. 
ação social e econômica que depois se complexificam está tratando de "instituições". Portanto, a ação social e econômica em situações mais complexas vai constituir-se em "instituições". Vamos destacar algumas dessas "instituições" abordadas por Weber, e que têm papel importante em sua sociologia econômica, como "propriedade", organização econômica, divisão e combinação do trabalho e mercado.

Weber fala de propriedade no parágrafo 10 do capítulo 1 de "Economia e Sociedade", no contexto de sua discussão sobre apropriação e relação social fechada. Ele diz que "(...) propriedade (do indivíduo, da comunidade ou da sociedade) [são] as possibilidades hereditariamente apropriadas por este ou aquelas; caso sejam alienáveis, designamo-las propriedade livre.” (1999, p. 27) Assinale-se que a propriedade, para Weber, até pode ter uma dimensão legal não sendo isso uma condição necessária para que ela exista.

A "instituição" organização econômica também é discutida, por Weber, no contexto de relações fechadas. A edição brasileira de "Economia e Sociedade" (1999) parece falar de "associação" e "comunidade" ao invés de organização. O parágrafo 12 do capítulo 1 trata de associação (organização) em geral, e diz: "Chamamos de 'associação' uma relação social fechada para fora ou cujo regulamento limita a participação quando a observação de sua ordem está garantida pelo comportamento de determinadas pessoas, destinado particularmente a esse propósito: de um dirigente e, eventualmente, um quadro administrativo que dado o caso, têm também, em condições normais, o poder de representação.” (p. 30) E no capítulo 2 da Segunda Parte do Volume 1 do mesmo livro ele diz:

A relação social pode orientar-se, de acordo com o sentido de algum modo subjetivamente concebido pelos participantes, por resultados puramente econômicos: satisfação de necessidades ou lucro. Constitui, no caso, o fundamento de uma comunidade econômica. Ou pode servir-se da gestão econômica própria como meio de obter outros resultados pelos quais se orienta: comunidades de gestão econômica. Ou, na orientação de uma ação social, combinam-se resultados econômicos e extra-econômicos. Ou, por fim, pode não se verificar nenhum dos casos. (WEBER, 1999, p. 230)

Swedberg (2005b) sintetiza esse caminho proposto por Weber e que sai do indivíduo, de sua ação social individual, passa pelas relações entre dois ou mais indivíduos que interagem e mostra como as ações econômicas dos indivíduos se transformam em: (a) organizações econômicas (por exemplo, a firma) que são relações sociais fechadas e impostas por equipes administrativas, (b) organizações economicamente ativas (por exemplo, a igreja), (c) organizações regulamentadoras (sindicatos) e (d) organizações que impõem uma ordem formal (o Estado liberal)..$^{14}$

A firma ou empresa capitalista é vista por Weber como a única organização econômica verdadeiramente "revolucionária" pois ao buscar a geração de lucro atra-

$\overline{14}$ Vide Swedberg, 2005b, p. 68, figura 2.2. 
vés da exploração de novas oportunidades, ela se apresenta ligada a um tipo específico de ação racional. E isto nega o tradicionalismo econômico e suas formas de explorar as oportunidades econômicas na esfera do mercado. Weber observa que as firmas com direitos adquiridos também podem tentar impedir a obtenção racional de lucros o que ameaçaria a dinâmica futura do capitalismo. ${ }^{15}$ Swedberg lembra que "Weber faz uma distinção entre a firma como organização racional de geração de lucro ("firma") e como entidade técnica ("estabelecimento"). Também faz uma descrição sumária da organização interna da firma capitalista típica.” (2005, p. 69)

Para tratar da instituição econômica de mercado, vamos utilizar os comentários de Swedberg (2005b). Ele diz que para Weber o mercado tem uma estrutura "amorfa”, mas tem uma estrutura social e pode ser encontrado num lugar específico. "Uma organização pode ou não ser responsável pelo mercado. Apesar disso, sua essência social consiste em atos de troca repetidos (...). É dirigida ao parceiro de troca (com quem se troca) e aos concorrentes (que são suplantados por uma oferta mais vantajosa). A primeira interação pressupõe um contato direto ("luta pelo preço"), ao passo que a segunda forma de relação é indireta ("luta entre concorrentes”) (p. 70)

Swedberg defende que a idéia básica de mercado de Weber pode ser dinamizada com a introdução dos conceitos de relações abertas e fechada. Pois alguns agentes econômicos podem querer fechar o mercado para novos entrantes e outros podem querer mantê-lo aberto.

Registre-se que em "Economia e Sociedade", Weber trata das formas pelas quais ocorre a regulação da liberdade do mercado, o que lembra a questão das relações econômicas fechadas. Essas formas seriam: pela lei, pela tradição, pela convenção ou regulação voluntária.

Segundo Weber, os mercados são antípodas dos grupos de status. Isto ocorre por que os mercados não se ocupam das qualidades pessoais ou da honra dos agentes, tudo o que importa é o que está sendo trocado. Logo o mercado dificilmente é influenciado por questões éticas e morais.

No capítulo 2 da Parte 1 do Volume 1 de "Economia e Sociedade”, Weber diz que não vai apresentar uma teoria de preços e ao longo deste livro ele faz observações favoráveis à teoria da utilidade marginal e a sua forma de explicar os preços. Entretanto ele, repetidamente fala que as lutas econômicas entre os agentes e outros elementos semelhantes de ação social determinam os preços. Pois para explicar os preços reais é preciso explicar o que acontece na prática e não só na teoria da utilidade marginal.

Acreditamos que as observações e comentários acima realizados sobre Weber nos ajudem a constituir um esboço de sua sociologia econômica que posteriormente vamos confrontar com a nova sociologia econômica de Granovetter. E para este mesmo fim vamos tratar da contribuição de enraizamento de Polanyi.

15 Esta colocação lembra a discussão estabelecida por Schumpeter em "Capitalismo, Socialismo e Democracia”. 
Vamos tratar somente do livro "A Grande Transformação" de Karl Polanyi. $\mathrm{O}$ autor defende que as economias pré-capitalistas estão enraizadas na tradição e na religião ao passo que a economia capitalista (ou nas suas palavras a economia de "mercado auto-regulado") não está. Mas estas conclusões quanto ao desenraizamento da sociedade dominada pelos mercados auto-regulados só surge após o autor discutir as causas e conseqüências do estabelecimento do "moinho satânico" e do "duplo movimento" inerentes à dinâmica expansiva do mercado auto-regulado.

Para Polanyi , a Revolução Industrial inglesa liberou um instrumento de produção com capacidades até então desconhecidas para produzir mercadorias ao mesmo tempo que permitia a redução dos seus custos de fabricação. Tal instrumento eram as máquinas complexas e os sistemas fabris que as utilizavam nos seus processos produtivos. Quando do seu surgimento, ganha força na sociedade inglesa a idéia do mercado auto-regulável. Ele ressalta que essa Revolução ocorre numa sociedade de perfil agrário e comercial na qual agricultores e comerciantes compram e vendem os produtos da terra. Mas com as máquinas complexas a produção dispendiosa de agora só pode se adaptar à sociedade existente, transformando esta sociedade. O comerciante é o agente que irá tomar a frente deste mecanismo. Ele venderá as mercadorias como sempre fez, mas não vai mais comprá-las prontas, vai adquirir trabalho e matéria-prima e fabricar o produto a ser vendido. São óbvias as conseqüências disto para a sociedade. Como as máquinas complexas envolvem um grande investimento inicial na sua construção e aquisição, é preciso que se produzam grandes quantidades de mercadorias com elas para diluir este custo fixo inicial. Logo, tanto os fluxos de venda das mercadorias fabricadas quanto o fluxo de compra de matéria-prima a ser processada não pode ser interrompido. Logo, para o comerciante que arrisca seu dinheiro nessa nova empreitada é fundamental que os fatores trabalho e matéria-prima, estejam disponíveis, para quem possa pagar por eles, nas quantidades necessárias para a continuidade do fluxo produtivo. Naturalmente, tais novidades levam a uma mudança radical no funcionamento da outrora sociedade agrícola. Agora a comunidade como um todo vai depender do fluxo contínuo de produção para obter renda, emprego e provisões. Muda, também, a motivação da ação do membro da sociedade. Antes o que o movia era a subsistência, agora a busca do lucro. Agora as transações são transações monetárias, o que exige a presença do dinheiro em cada espaço da vida industrial. "Todas as rendas devem derivar da venda de alguma coisa e, qualquer que seja a verdadeira fonte de renda de uma pessoa, ela deve ser vista como resultante de uma venda. (...) [Este sistema de mercado] uma vez estabelecido, tem que se lhe permitir funcionar sem interferência externa. Os lucros não são mais garantidos e o mercador tem que auferir seus lucros no mercado. Os preços devem ter a liberdade de se auto-regularem." (Polanyi, 2000, p. 60)

Polanyi conclui que o mercador-produtor vende apenas "artefatos", e se não houver demanda para eles "o tecido da sociedade não precisa ser afetado" (Polanyi, 2000, p. 61). Entretanto, para que haja produção, ele compra matérias-primas (natureza) e trabalho (homem) - segundo Polanyi (Polanyi, 2000, p. 61) "a produção de 
máquinas numa sociedade comercial envolve uma transformação que é a da substância natural e humana da sociedade em mercadorias" - caso ele não encontre demanda para seus artefatos, suas compras de matérias-primas e trabalho diminuirão. A conclusão inevitável é de que: "Obviamente, a desarticulação causada por tais engenhos deve desorganizar as relações humanas e ameaçar de aniquilamento o seu babitat” (ibid.)

Assim Polanyi demarca sua discordância com as "robinsonadas" típicas da economia vulgar lembrando que a sociedade de mercado auto-regulado é uma criação recente na história humana. E recorrendo a antropologia aponta que nas sociedades primitivas não existia a modificação do homem como ser social, ou dizendo o mesmo de outro modo, nela a economia do homem está submetida, enraizada, em suas relações sociais. $\mathrm{O}$ sistema econômico é dirigido por motivações não-econômicas, não se trata de buscar o máximo lucro, mas de cumprir exigências sociais, garantir sua situação social e seu patrimônio social. A pergunta chave então é como, nas sociedades primitivas, se garantia a ordem na produção e distribuição de valores de uso ${ }^{16}$. A resposta dada por Polanyi, ainda com base na antropologia, é que "dois princípios de comportamento não associados basicamente à economia [estão agindo]: reciprocidade e redistribuição." (Polanyi, 2000, p. 67). Além do princípio da domesticidade.

O princípio de comportamento de reciprocidade "atua principalmente em relação à organização sexual da sociedade, isto é, família e parentesco” (Polanyi, 2000, p. 67). A subsistência familiar e a produção são salvaguardadas pela reciprocidade. A reciprocidade, que nos povos ditos "não-civilizados" garante (junto com a redistribuição) o funcionamento do sistema produtivo - mesmo na ausência de registros escritos e um aparato administrativo específico - é "facilitada pelo padrão institucional da simetria” (Polanyi, 2000, p. 68). A simetria é encontrada nas subdivisões da tribo, na localização dos povoados e nas relações intertribais, o que garante uma ampla reciprocidade que não poderia ser verificada caso fosse fundada em atos isolados de troca.

O princípio de comportamento de redistribuição “(...) é importante principalmente em relação a todos aqueles que têm uma chefia em comum e têm, assim, um caráter territorial” (Polanyi, 2000, p. 67) Aqui uma parte importante da produção da aldeia é entregue ao chefe geral que a armazena e quando das atividades comunais (festas, danças, etc) os redistribui. Mas esse sistema econômico tem motivações não-econômicas. $\mathrm{O}$ padrão institucional da centralidade vai cumprir para o princípio da redistribuição a mesma função que o padrão institucional da simetria cumpri para a reciprocidade. Para Polanyi o princípio da centralidade está de algum modo presente em todos os grupos humanos e orienta-os "para a coleta, armazenagem e redistribuição de bens e serviços” (Polanyi, 2000, p. 68-69). Daí ele conclui dizendo que simetria e centralidade respondem às necessidades da reciprocidade e

16 Polanyi não parece se preocupar com a correção no uso das categorias econômicas. Assim, ele chama qualquer coisa de mercadoria mesmo não tendo sido ela produzida para o mercado, ou seja, mesmo não possuindo valor de uso, valor de troca e valor em abstrato, vide o último parágrafo da página 69. Voltaremos a essas observações críticas a ele, a Weber e a Granovetter, após termos exposto as linhas gerais da ontologia marxiana do ser social. 
redistribuição de tal forma que ambos (padrões institucionais e princípios de comportamento) se ajustam entre si. E nesse contexto, de normalidade, fica garantida a divisão social do trabalho e afastada a intervenção de qualquer motivação econômica individual como a busca de lucro. Logo não há espaço para regateios, barganhas, etc, a virtude é encarnada pela doação, pela dádiva. "Na verdade, o sistema econômico é mera função da organização social” (Polanyi, 2000, p. 69).

Polanyi adverte para o fato de que esses princípios e padrões não estão restritos a produtores primitivos, comunidades pequenas ou algo similar. Para ele uma economia sem lucro e sem mercado não precisa ser simples, e dá como exemplos de comunidades complexas que utilizavam um ou mais desses princípios o circuito Kula da Melanésia Ocidental, o reinado de Hamurabi na Babilônia, o novo Império do Egito, a antiga China, o império dos Incas, etc.

O terceiro princípio é o da domesticidade que "consiste na produção para uso próprio". (Polanyi, 2000, p. 73) Ele não é mais antigo que os princípios da reciprocidade e da redistribuição, mas só ganha destaque quando a agricultura atinge um patamar mais avançado para garantir a satisfação das necessidades domésticas. $\mathrm{O}$ padrão institucional da domesticidade é a autarquia, o grupo fechado, para o qual se produzia e armazenava visando à satisfação de suas necessidades.

Polanyi reafirma que até o fim do feudalismo na Europa Ocidental, todos os sistemas econômicos foram organizados pelos princípios da reciprocidade, redistribuição ou domesticidade ou uma combinação deles. E nessa

(...) estrutura, a produção ordenada e distribuição dos bens era assegurada através de uma grande variedade de motivações individuais, disciplinadas por princípios gerais de comportamento. E entre essas motivações, o lucro não ocupava lugar proeminente. Os costumes e a lei, a magia e a religião cooperavam para induzir o indivíduo a cumprir as regras de comportamento, as quais, eventualmente, garantiam o seu funcionamento no sistema econômico. (POLANYI, 2000, p. 75)

A partir do século XIX, com o advento da revolução industrial e das máquinas complexas, o mercado adquire um lugar central na vida econômica. $\mathrm{O}$ princípio de comportamento da permuta, da troca, depende do padrão de mercado para sua efetivação. O princípio da permuta pode ocorrer sem ocupar um papel central numa sociedade, desde que os outros princípios sejam dominantes. Mas enquanto os padrões de simetria, centralidade e autarquia não criam instituições específicas para uma única função, o padrão de mercado cria - o próprio mercado. Daí que o controle do sistema econômico pelo mercado implica em

(...) dirigir a sociedade como se fosse um acessório do mercado. Em vez de a economia estar embutida nas relações sociais, são as relações sociais que estão embutidas no sistema econômico. A importância vital do fator econômico para a existência da sociedade antecede qualquer outro resultado. Desta vez, o sistema econômico é organizado em ins- 
tituições separadas, baseado em motivos específicos e concedendo status especial. A sociedade tem que ser modelada de maneira tal a permitir que o sistema funcione de acordo com as suas próprias leis. Este é o significado da afirmação familiar de que uma economia de mercado só pode funcionar numa sociedade de mercado. (POLANYI, 2000, p. 77)

Agora a questão é explicar a transformação de mercados isolados em uma economia de mercado, mercados reguláveis num mercado auto-regulável. O fato é que tal transformação não foi resultado natural da difusão dos mercados - pois para Polanyi eles têm uma natureza não expansiva. Mas o resultado de intervenções estatais que tinham por objetivo fazer frente às tendências dissolutivas do padrão social prevalecente pela atuação do mercado e pelas tendências iniciadas com o predomínio da máquina.

Construindo a gênese dos mercados Polanyi assinala que eles

não são instituições que funcionam principalmente dentro de uma economia, mas fora dela. Eles são locais de encontro para um comércio de longa distância. [Numa sociedade primitiva] Os mercados locais, propriamente ditos, são de pouca importância. Além disso, nem os mercados de longa distância, nem os mercados locais são essencialmente competitivos. Consequentemente, tanto num como noutro caso é pouca a pressão para se criar um comércio territorial, o assim chamado mercado interno ou nacional. (POLANYI, 2000, p.78)

Demarcando sua diferença de compreensão com a "doutrina clássica”, ele defende que a origem do comércio se encontra numa esfera externa a comunidade, não estando relacionado com a organização interna da economia. E esse comércio de longa distância é entendido como "(...) resultado da localização geográfica das mercadorias e da 'divisão do trabalho' dada pela localização" (Polanyi, 2000, p. 79). Eventualmente pode até engendrar mercados o que vai permitir a barganha e o regateio que a "doutrina clássica" vê como propensão natural do ser humano. Entretanto, o comércio externo prescindia do mercado, pois estaria mais calcado na aventura, caça, guerra, etc. do que na permuta. Naturalmente o autor reconhece que em fases posteriores os mercados se tornam predominantes no comércio exterior. Ainda que a crítica à "doutrina clássica" seja pertinente, ela peca ao não perceber que o fator que determina em última instância a existência do comércio, mesmo a longa distância, é o aumento de produtividade da comunidade e que por sua vez só pode ser obtido com o aumento da divisão social do trabalho no seio da comunidade.

Voltando a gênese dos mercados, Polanyi lembra que mercados externos, locais e internos/nacionais são diferentes entre si no tamanho, funções e origens. Quanto aos mercados externos, apontamos alguns dos seus traços nos parágrafos anteriores. $\mathrm{O}$ mercado local limita-se ao comércio de mercadorias da região que por motivos de tamanho, peso ou por serem perecíveis não podem ser transportados por longas distâncias. Eles são mercados de vizinhança e não iniciaram o comércio interno ou nacional. Além disso, não são os atos individuais que favoreceram o surgimento do 
mercado local nas “(...) sociedades em que predominam outros princípios de comportamento econômico." (Polanyi, 2000, p. 81) O comércio externo é que favoreceu o desenvolvimento de mercados locais nos lugares de parada dos mercadores. Mas, nas sociedades mais primitivas existiam um conjunto de limitações contra a ampliação da influência do mercado na vida social - costume, lei, religião, magia, etc. E Polanyi frisa que mesmo as cidades e a civilização urbana, que seriam produtos do desenvolvimento dos mercados locais, tiveram um papel de impedir a expansão das práticas do mercado pelo campo e de se enraizarem na vida econômica da sociedade mais primitiva.

O mercado interno ou nacional, para Polanyi, foi criado pela intervenção do Estado. Isto como reação a separação operada na sociedade europeia medieval entre o comércio local e o comércio a longa distância. Tal separação "(...) foi a reação da vida urbana à ameaça do capital móvel de desintegrar as instituições da cidade." (Polanyi, 2000, p. 85-86) Pois o mercado local era controlável e o comércio de exportação não. ${ }^{17}$ Assim, as cidades medievais obstaculizaram a formação do mercado nacional ou interno. E o Estado nacional viu-se obrigado a criar o mercado interno/ nacional. Ao longo dos séculos XV e XVI, utilizando-se dos princípios mercantilistas, o Estado derrubou as barreiras entre o comércio local e intermunicipal, passou a ignorar as diferenças entre campo e cidade e entre as cidades e províncias. Ou seja, atacou frontalmente o protecionismo arraigado nas cidades, libertando o comércio dos limites da cidade (Polanyi, 2000, p. 86-87). Mas as cidades protecionistas até então tinham conseguido evitar, com sucesso, dois perigos: o monopólio e a competição ${ }^{18}$. A solução dada pelo Estado “(...) foi a total regulamentação da vida econômica, só que agora em escala nacional e não mais apenas municipal”. (Polanyi, 2000, p. 86-87) Esse movimento visava em última instância defender o próprio funcionamento dos mercados naquelas circunstâncias, pois a ruptura do equilíbrio entre oferta e procura poderia levar a paralisia do próprio mercado. Nesse caso os ofertantes tradicionais deixam de ofertar por não terem garantia de preço e o mercado se encaminha para uma situação de monopólio. O mesmo valendo para o lado da demanda. Assim, o fim das restrições, tributos e proibições sobre o mercado que era conseguido pela intervenção de Estado, facilitava a atuação de "aventureiros" que desestabilizavam os mercados e não garantiam a sua permanência nos mesmos. Daí dizer Polanyi que “(...) embora os novos mercados nacionais até certo ponto fossem competitivos, inevitavelmente, o que prevalecia era o aspecto tradicional da regulamentação e não o novo elemento da competição." (Polanyi, 2000, p. 87)

Em termos de gênese dos mercados, segundo Polanyi, estamos num momento em que as práticas mercantilistas livraram o comércio das particularidades locais,

17 Por exemplo, no que diz respeito a fabricação de tecidos para a exportação, a forma de organização do trabalho se dava com base no trabalho assalariado fugindo do controle das guildas e corporações de ofício. Vide Polanyi, 2000, p. 85.

18 Segundo Polanyi $(2000$, p. 87 ) já existia o entendimento de que a concorrência poderia levar ao monopólio, mas o monopólio era muito mais temido pois poderia pôr em perigo a comunidade pois estava ligado às necessidades da vida. 
mas ao mesmo tempo houve um aumento da regulamentação. "O sistema econômico estava submerso em relações sociais gerais; os mercados eram apenas um aspecto acessório de uma estrutura institucional controlada e regulada, mais do que nunca, pela autoridade social”. (Polanyi, 2000, p. 88) Isso se verifica até as vésperas da Revolução Industrial Inglesa, mas daí em diante teremos o mercado auto-regulável. É importante destacar que para Polanyi os mercados e as regulações nasceram juntos, ao contrário do que imagina a economia vulgar (neoclássica). O surgimento do mercado auto-regulável contraria a tendência de desenvolvimento existente até esse momento. E uma economia de mercado só pode existir enquanto um sistema econômico hegemonizado pelos mercados, de tal forma que a produção, a distribuição e o consumo são dominados pela atuação do mercado auto-regulável. A produção e a distribuição de mercadorias são reguladas apenas pelos preços. Os preços devem operar de tal forma a garantir a igualação entre oferta e demanda das mercadorias. E isto só será possível se os indivíduos buscam sistematicamente o máximo lucro em termos monetários. Logo é preciso a presença do dinheiro, e ressalta-se a centralidade dos preços para o funcionamento de todo o sistema econômico. No mercado auto-regulado toda produção é destinada ao mercado e todos os rendimentos são obtidos pela venda das mercadorias. Sendo necessário existir mercados para todos os bens e serviços assim como para o trabalho, a terra e o dinheiro.

Polanyi (2000) chama de mercadorias fictícias o trabalho, a terra e o dinheiro, defendendo que de fato não são mercadorias. Incorrendo assim em grave erro científico, mas que não chega a surpreender diante de sua recusa em operar com a teoria do valor trabalho enquanto teoria explicativa dos preços, e de sua definição tautológica de lucro: “(...) sendo a renda chamada de lucro, na verdade a diferença entre dois conjuntos de preços, o preço dos bens produzidos e seus custos, i.e., o preço dos bens necessários para produzi-los” (p. 90).

Antes de tratarmos das mercadorias fictícias com mais detalhes, vamos tratar de outros pressupostos para a existência de mercados auto-reguláveis. No que diz respeito ao Estado e a política, não devem ser adotadas quaisquer medidas ou políticas econômicas que alterem a ação dos mercados auto-regulados. A formação de preços e os rendimentos só podem ter por base a venda das mercadorias. Logo, oferta e demanda também não podem ser reguladas ou fixadas. As únicas políticas válidas e aceitáveis são aquelas que garantam a auto-regulação do mercado de forma a permitir que o mercado seja o único organizador da vida econômica. Polanyi ressalta que antes da era dos mercados auto-regulados a transferência e restrições, direitos de propriedade, formas de uso, etc sobre a terra e o trabalho "(...) ficavam à parte da organização da compra e venda, e sujeitas a um conjunto inteiramente diferente de regulamentações institucionais”. (Polanyi, 2000, p. 91) Assim, a atividade produtiva estava enraizada na organização da sociedade, nas relações sociais. Com os mercados auto-regulados isso deixa de ocorrer.

Por isso, o mercado auto-regulado não pode prescindir da “(...) separação institucional da sociedade em esferas econômica e política”. (Polanyi, 2000, p. 92) 
Assim, a sociedade passa a se subordinar as exigências dos mercados auto-regulados, logo a economia de mercado exige uma sociedade de mercado. E, como assinalamos mais acima, para Polanyi a economia de mercado deve subjugar todos os produtos $\mathrm{da}$ indústria além do trabalho, da terra e do dinheiro. E a terra e o trabalho nada mais são do que o meio ambiente e os seres humanos, e a sociedade é constituída pelos seres humanos e existe no meio ambiente, na natureza. Daí diz Polanyi: "Incluí-los no mecanismo de mercado significa subordinar a substância da própria sociedade às leis do mercado". (Polanyi, 2000, p. 93) Mas, como também já assinalamos, trabalho, terra e dinheiro não são mercadorias, para Polanyi na verdade são mercadorias fictícias. E, para ele, os mercados de trabalho, terra e dinheiro são organizados com base nessa ficção. E quaisquer políticas que tentassem travar tais mercados colocariam em risco o próprio sistema auto-regulado. Mas permitir que esse "moinho satânico" atue levará ao desmoronamento da própria sociedade. Daí ele concluir que: "A história social do século XX foi, assim, o resultado de um duplo movimento; a ampliação da organização do mercado em relação às mercadorias genuínas foi acompanhada pela sua restrição em relação às mercadorias fictícias" (Polanyi, 2000, p. 98).

Um balanço preliminar da contribuição de Polanyi é que ele acertadamente ressalta a importância do enraizamento das relações econômicas nas relações sociais nas comunidades primitivas, mas parece forçar demais o argumento ao desconsiderar as formas de enraizamento presentes na sociedade dominada pelo modo de produção capitalista plenamente desenvolvido. É nesse sentido que argumenta Swedberg (2005b, p. 92-93; nota: 44):

Nesse artigo ['Economic Action and Social Structure: The Problem of Embeddedness' - Mark Granovetter], bem como em conversas com o autor, Granovetter afirma a afinidade entre a sociologia econômica de Weber e sua própria análise da imbricação [enraizamento]. Karl Polanyi, é preciso acrescentar, via a 'imbricação' [enraizamento] de uma forma diferente: as economias pré-capitalistas, dizia ele, estão imbricadas [enraizadas] na religião e na tradição, ao passo que as economias capitalistas não estão: (...) (SWEDBERG, 2005b, p. 92-93; nota: 44).

\section{Granovetter e a nova sociologia econômica}

A nova sociologia econômica surge no início dos anos 80 do século XX, sendo que o marco da sociologia econômica moderna é o artigo de Granovetter "Economic Action and Social Structure: The Problem of Embeddedness" de 1985. Este artigo realiza uma crítica brilhante (Swedberg, 2003, p. 230) à Nova Economia Institucional e desloca a crítica à economia neoclássica do conceito irreal de racionalidade dos agentes para sua incapacidade de endogeneizar as estruturas sociais no seu corpo científico. Para Granovetter trata-se de considerar na análise tanto atores racionais quanto as estruturas sociais por eles constituída. Assim ele nega o que ele identifica como concepções sobressocializadas e subsocializadas do homem na 
economia e na sociologia.

A principal diferença entre a nova e a velha sociologia econômica é que a nova busca questionar as teorias neoclássicas em seus fundamentos, a velha não tinha tal ousadia. Ela simplesmente aceitava o postulado de que os indivíduos são maximizadores de funções de utilidade e se encontram separados uns dos outros, atomizados. Para a nova sociologia econômica os indivíduos não estão separados, mas envolvidos em interações através de estruturas específicas que precisam ser analisadas teoricamente. Aqui o conceito de "enraizamento" é introduzido. Ele se apresenta enquanto antípoda da noção de indivíduo atomizado. Conforme lembra Swedberg (2003), para Polanyi, a economia estava “enraizada” nas sociedades pré-capitalistas, Granovetter tenta mostrar que na sociedade capitalista o agir econômico é necessariamente um agir social. Sendo fato que apesar de dizer que é necessário um desenvolvimento do conceito de "enraizamento", ele próprio não completou até agora este desenvolvimento. Como o agir econômico está enraizado no agir social, ele propõe a compreensão deste agir social no contexto de redes sociais. Ou seja, o agir econômico encontra-se "enraizado" em redes de relações sociais, interpessoais.

Em um artigo de 1991 ("Economic Institutions as Social Constructions: A Framework for Analysis”) Granovetter introduz o conceito de "construção social da economia”. Enquanto que para a Nova Economia Institucional as instituições têm um caráter natural, perene, sendo a única possível para cumprir as funções que cumpre e reduzindo custos de transação. Para Granovetter, partindo do conceito de "construção social da economia", as redes de relações interpessoais têm um papel importante, fundamental, nos momentos anteriores à formação de uma instituição. Depois de formada a instituição, a importância das redes interpessoais diminui. Ele exemplifica isto com o caso da indústria norte-americana de distribuição de eletricidade e as redes articuladas por Samuel Insull.

Do exposto até aqui, podemos apontar que as contribuições de Durkheim, Weber e Polanyi, têm grande importância para a construção teórica de Granovetter e da Nova Sociologia Econômica. Para o real domínio da contribuição de Granovetter e sua possível crítica da perspectiva ontológica, faz-se necessário realizarmos um esforço de apreensão dos liames teóricos propostos por ele nos artigos por nós selecionados a partir de sua relevância para a construção teórica do autor.

Iniciando com o artigo “The Strength of Weak Ties” de 1973, Granovetter aponta a preocupação em apresentar uma proposta de ponte teórica entre os níveis macro e micro de análise do sistema social, pois entende que a teoria sociológica não apresenta de forma convincente a intersecção entre estes níveis. Acredita que a força dos vínculos interpessoais que ocorrem concretamente nas interações em pequena escala, pode ser relacionado com vários fenômenos macro como “(...) diffusion, social mobility, political organization, and social cohesion in general” (1973, p. 1361).

Para o autor a noção intuitiva de força de um vínculo interpessoal pode ser apresentada da seguinta forma:“(...) the strength of a tie is a (probably linear) combination of the amount of time, the emotional intensity, the intimacy (mutual 
confiding), and the reciprocal services which characterize the tie. Each of these is somewhat independent of the other, though the set is obviously highly intracorrelated" (idem). E quanto a tipologia dos laços o autor diz que: "It is sufficient for the present purpose if most of us can agree, on a rough intuitive basis, whether a given ties is strong, weak, or absent" (ibid.).

A relação entre os vínculos duais e o nível macro, as grandes estruturas, é demonstrada por Granovetter (1973, p. 1362) a partir da hipótese de dois indivíduos A e B escolhidos arbitrariamente e um conjunto de indivíduos ("S = C, D, E, ...”) que se relaciona com A, com B ou com ambos. Assim, "The hypothesis which enables to related dyadic ties to larger structures is: the stronger the tie between $A$ and $\mathrm{B}$, the larger the proportion of individuals is $\mathrm{S}$ to whom they will both be tied, that is, connected by weak or strong tie. This overlap in their friendship circles is predicted to be least when their tie is absent, most when it is strong, and intermediate when it is weak" (ibid.). O autor prossegue argumentando que os laços fortes terminam por se tornarem compromissos de longo prazo. Assim, se A se relaciona com $\mathrm{B}$ e com $\mathrm{C}$, e se $\mathrm{B}$ e $\mathrm{C}$ não têm relação, os laços de $\mathrm{B}$ e $\mathrm{C}$ com $\mathrm{A}$ provavelmente levarão ao surgimento de alguma interação entre eles (B e C).

Formulando de forma mais precisa as implicações para grandes redes de relações, Granovetter vai tratar da tríade proibida. Sua investigação foca sobre a existência de laços fortes, fracos ou ausentes entre $\mathrm{A}$ e $\mathrm{B}$ e um membro $\mathrm{C}$ do conjunto $\mathrm{S}$. A tríade menos provável de ser verificada é aquela em que $\mathrm{A}$ e $\mathrm{B}$ estão fortemente unidos, “(...) A has a strong tie to some friend $\mathrm{C}$, but the tie between $\mathrm{C}$ and $\mathrm{B}$ is absent. This trial is shown in figure 1. To see the consequences of this assertion, I will exaggerate it in what follows by supposing that the triad shown never occurs - that is, that $\mathrm{B}-\mathrm{C}$ tie is always present (whether weak or strong), given the other two strong ties. Whatever results are inferred form this supposition should tend to occur in the degree that the triad in question tends to absent".

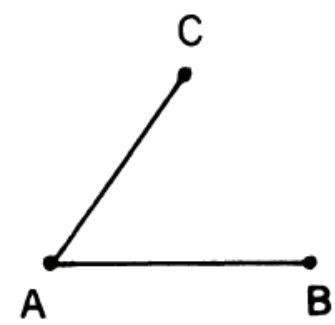

FIG. 1.-Forbidden triad

(1973, p. 1363)

O significado da tríade proibida é desvelado com o uso do conceito de ponte. Ponte seria uma linha numa rede que “(...) provides the only path between two points (...). Since, in general, each person has a great many contacts, a bridge be- 
tween $\mathrm{A}$ and $\mathrm{B}$ provides the only route along which information or influence can flow from any contact of A to any contact of B, and, consequently, from anyone connected indirectly to A anyone connected indirectly to B. Thus, in the study of diffusion, we can expect bridges to assume an important role”. (1973, p. 1364)

Granovetter prossegue argumentando que estando a tríade ausente o mais provável é que um vínculo fraco apresente-se como uma ponte. Vejamos:

Consider the strong tie A-B: if A has another strong tie to C, then forbidding the triad of figure 1 implies that a tie exists between $\mathrm{C}$ and $\mathrm{B}$, so that the path $\mathrm{A}-\mathrm{C}-\mathrm{B}$ exist between $\mathrm{A}$ and $\mathrm{B}$; hence, $\mathrm{A}-\mathrm{B}$ is not a bridge. A strong tie can be a bridge, therefore, only if neither party to it has any other strong ties, unlikely in a social network of any size (though possible in a small group). Weak ties suffer no such restriction, though they are certainly not automatically bridges. What is important, rather, is that all bridges are weak ties (GRANOVETTER, 1973, p. 1364).

O autor adverte que em grandes redes só raramente um vínculo específico proporciona um caminho único entre dois pontos, mas esta função de ponte pode ser servida localmente. Ao tratar disto ele apresenta a idéia de grau de uma ponte. "I will refer to a tie as a 'local bridge of degree n' if $n$ represents the shortest path between its two points (other than itself), and $n>2$. (..) As with bridges in a highway system, a local bridge in a social network will be more significant as a connection between two sectors to the extent that it is the only alternative for many people - that is, as its degree increases. A bridge in the absolute sense is a local one of infinite degree. By the same logic used above, only weak ties may be local bridges” $(1973,1365)$.

Tomando a sugestão de Davis, Granovetter defende que em interações entre dois indivíduos quaisquer, a probabilidade de que ocorra um fluxo de informações entre eles dependerá de forma diretamente proporcional do número de relacionamentos de amizade (que são caminhos que conectam ambos) que ocorrem entre eles e de forma inversamente proporcional da extensão destes caminhos. Os laços fracos que forem pontes locais criarão mais caminhos e mais curtos. Daí Granovetter arremata dizendo:

Intuitively speaking, this means that whatever is to be diffused can reach a larger number of people, and traverse greater social distance (i.e., path length), when passed through weak ties rather than strong. If one tells a rumor to all his close friends, and they do likewise, many will hear the rumor a second and third time, since those linked by strong ties tend to share friends. If the motivation to spread the rumor is dampened a bit on each wave o retelling, then the rumor moving through strong ties is much more likely to be limited to a few cliques than that going via weak ones; bridges will not be crossed (Granovetter, 1973, p. 1366).

Quanto à tendência da literatura especializada de enfatizar que ou o comportamento do indivíduo é formado e limitado pela rede ou que os indivíduos podem manipular as redes para conseguir objetivos específicos, Granovetter se posiciona 
associando tal questão à outra que também carece de acordo na literatura: redes de ego (“ego's network") devem ser tratadas como compostas só por aqueles a quem ego está diretamente ligado ou devem incluir os contatos dos seus contatos. Assim ele defende que:

Analyses stressing encapsulation of an individual by his network tend to take the former position, those stressing manipulation of networks, the latter, since information or favors available through direct contacts may depend on who their contacts are. I would argue that by dividing ego's network into that part made up of strong and nonbridging weak ties on the one hand, and that of bridging weak ties on the other, both orientations can be dealt with. Ties in the former part should tend to be to people who not only know one another, but who also have few contacts not tied to ego as well. In the 'weak' sector, however, not only will ego's contacts not be tied to one another, but they will be tied to individuals not tied to ego. Indirect contacts are thus typically reached through ties in this sector; such ties are then of importance not only in ego's manipulation of networks, but also in that they are the channels through which ideas, influences, or information socially distant from ego may reach him. The fewer indirect contacts one has the more encapsulated he will be in terms of knowledge of the world beyond his own friendship circle; thus, bridging weak ties (and the consequent indirect contacts) are important in both ways (GRANOVETTER, 1973, p. 1370-71).

Tal proposta de Granovetter se desdobra no exemplo do mercado de trabalho. $\mathrm{Na}$ busca por emprego, os laços fortes de um indivíduo que busca emprego estão motivados a ajudá-lo com informações sobre oportunidades de colocação, mas o alcance dos laços fortes é limitado o que limita o alcance das informações. Tal não ocorre com os laços fracos que são constituídos por indivíduos que movem-se por círculos diferentes do indivíduo que busca emprego e têm acesso a informações diferentes das que este indivíduo possui usualmente. Assim, para os indivíduos, os laços fracos tornam possível a oportunidade de mobilidade e, para o nível macro, os laços fracos reforçam a coesão social efetiva. Pois a troca de emprego, por parte de um indivíduo, implica que ele se movimenta entre laços diferentes e, ao mesmo tempo, estabelece uma união entre estes laços. Com isto, as idéias fluem entre grupos e constroem um "sentido de comunidade". ${ }^{19}$

19 "From the individual's point of view, then, weak ties are an important resource $\mathrm{n}$ making possible mobility opportunity. Seen from a more macroscopic vantage, weak ties play a role in effecting social cohesion. When a man changes jobs, he is not only moving from one network of ties to another, but also establishing a link between these. Such a link is often of the same kind which facilitated his own movement. Especially within professional and technical specialties which are well defined and limited in size, this mobility sets up elaborate structures of bridging weal ties between the more coherent clusters that constitute operative networks in particular locations. Information and ideas thus flow more easily through the specialty, giving it some 'sense of community', activated at meetings and conventions. Maintenance of weak ties may well be the most important consequence 
Granovetter encerra este artigo sinalizando que seu modelo de sistema interpessoal não é voltado para pequenos grupos ou grupos reduzidos e alocados em postos institucionais ou organizacionais. Mas tem por foco unir estes níveis de pequena escala a outros maiores e mais complicados. "This is why emphasis here has been placed more on weak ties than on strong. Weak ties are more likely to link members of different small groups than are strong ones, which tend to be concentrated within particular groups" (1973, p. 1376). E por fim acrescenta que "The major implication intended by this paper is that the personal experience of individuals is closely bound up with larger-scale aspects of social structure, well beyond the purview or control of particular individuals” (1973, p. 1377).

O segundo artigo de Granovetter escolhido pela sua relevância e impacto foi publicado originalmente em 1985 no American Journal of Sociology e intitula-se "Economic Action and Social Structure: The Problem of Embeddedness". Como o título enuncia, o autor preocupa-se em discutir a forma como os comportamentos individuais e as instituições humanas são afetados pelas relações sociais, o que, lembra ele, é uma questão clássica para a teoria social. Ele assinala que é possível dividir a compreensão da influência das relações sociais entre uma concepção sobressocializada do homem ("a conception of people as overwhelming sensitive to the opinions of others and hence obedient to the dictates of consensually developed systems of norms and values, internalized through socialization, so that obedience is not perceived as a burden" (1992, p. 54).) e uma concepção atomizada e subsocializada do homem ("In the undersocialized account, atomization results from narrow utilitarian pursuit of sel-interest" (1992, p. 56).), pouco influenciada pelas relações sociais. Diante destas alternativas consideradas por ele como insatisfatórias, é apresentada a proposta de enraizamento (“(...) the behavior and institutions to be analyzed are so constrained by ongoing social relations that to construe them as independent is a grievous misunderstanding” (1992, p. 53).). Neste artigo, o foco é para o enraizamento do comportamento econômico.

Assinala que a visão da chamada escola substantivista de Karl Polanyi, entende que o comportamento econômico, nas sociedades pré-mercantis, era fortemente enraizado nas relações sociais e com a dominação das sociedades mercantis ele se tornou mais autônomo. Nestas últimas as transações econômicas já não são definidas por obrigações sociais ou familiares, mas pelo cálculo racional do lucro individual dos agentes econômicos. "It is sometimes further argued that the traditional situation is reversed: instead of economic life being submerged in social relations, these relations become an epiphenomenon of the market” (1992, p. 53)”.

Mas o autor lembra que entre os economistas profissionais, poucos aceitam a ideia de que há um declínio do enraizamento devido ao processo de modernização mercantil das sociedades. A maioria entende que o enraizamento verificando nas sociedades pré-mercantis não era muito diferente do verificado nas sociedades mer-

of such meetings" (1973, p. 1373). 
cantis. O marco inicial de tal perspectiva foi dado por Smith, posteriormente a chamada "nova economia institucional" (North, Williamson, etc) retomou o interesse pelo estudo das instituições sociais. Para esta escola do pensamento econômico, “(...) behavior and institutions previously interpreted as embedded in earlier societies, as well as in our own, can be better understood as resulting from the pursuit of self-interest by rational, more or less atomized individuals" (1992, p. 54).

Granovetter distingue-se destas duas perspectivas por entender que o nível de enraizamento nas sociedades pré-mercantis é menor do que o postulado pela escola substantivista de Polanyi, e que o grau de enraizamento mudou menos com a passagem para as sociedades mercantis do que o que defende esta escola. Por outro lado, ele entende que o nível de enraizamento nas sociedades mercantis é maior e mais substancial do que o considerado pelos economistas em geral e pela "nova economia institucional” em particular. Ele adianta que não irá discutir neste artigo questões das sociedades pré-mercantis, mas vai desenvolver teoricamente o conceito de enraizamento, ilustrando-o com uma questão chave para a "nova economia industrial": "which transaction in modern capitalist society are carried out in the market, and which subsumed within hierarchically organized firms? (1992, p. 54).

No âmbito da sociologia moderna, assinala nosso autor, Talcott Parsons havia reconhecido o problema da ordem colocado originalmente por Hobbes ${ }^{20}$. Sendo que Hobbes trabalhava com uma concepção atomizada e subsocializada do homem, concepção idêntica à da tradição utilitarista. Parsons, na tentativa de superar tal concepção desenvolveu outra concepção na qual o homem encontra-se sobressocializado e seus padrões de comportamento são interiorizados de modo que as relações sociais nas quais eles estão inseridos têm efeito pequeno sobre eles. Em 1961 Dennis Wrong, também segundo nosso autor, advertia para o predomínio desta concepção sobressocializada na sociologia e para a necessidade de romper com o utilitarismo atomista e concordava com a ênfase dada ao enraizamento dos indivíduos no contexto social, ainda que advertindo para o risco de haver um exagero na aceitação do nível de enraizamento e para o risco da noção de enraizamento eliminar o conflito da análise.

Passando para a análise da economia clássica e neoclássica, assinala que ambas seguem a tradição utilitarista na qual a ação humana é atomizada e subsocializada. Não há relação de determinação entre estrutura social, relações sociais e as atividades de produção, distribuição e consumo. A estrutura de mercado de concorrência perfeita com seu grande número de compradores e vendedores impede que quaisquer deles influenciem os preços ou quantidades negociadas, não há barganha para alterar preço, não há reclamação, ajustamentos mútuos, etc., além disto não há contato humano prolongado o que impede relações duradouras entre os agentes. Esta estrutura de auto-regulação é, para muitos, politicamente interessante. E, além dis-

\footnotetext{
20 "In Hobbes's argument, disorder arises because conflict-free social and economic transaction depend on trust and the absence of malfeasance. But these are unlikely when individuals are conceived to have neither social relationships nor institutional context - as in the 'state of nature"' $(1985$, p. 55).
} 
so, garante a interdição do problema da ordem de Hobbes. Pois se a economia é entendida como algo sem relações sociais duradouras e desprovida de instituições, não há espaço para desconfiança e má-fé. Ou seja, ao contrário da proposta de Hobbes de uma autoridade autocrática que garanta a ordem a partir do seu aparato repressivo, a ideia do liberalismo difundida pela escola neoclássica é de que a concorrência perfeita interdita o uso da força, da fraude ou da má-fé. Primeiro por que todos os agentes conhecem perfeitamente os mercados. Segundo as informações estão disponíveis a custo zero. E por fim, se por acaso surgirem desconfianças quanto ao comportamento de algum agente, pode-se recorrer a outro agente que se comporte de acordo com o mercado de concorrência perfeita. Por isso, relações sociais e o contexto institucional tornam-se sem importância. Quando muito são obstáculos circunstanciais para o funcionamento adequado da concorrência perfeita.

Granovetter ressalta a ironia (segundo ele de grande importância teórica) de que as concepções subsocializadas e sobressocializadas estão de acordo quanto ao fato de que as ações e decisões dos agentes são tomadas por atores atomizados. Para a concepção subsocializada, "atomization results from narrow utilitarian pursuit of sel-interest” (1992, p. 56). Para a concepção sobressocializada resulta do “(...) fact that behavorial patterns have been internalized and ongoing social relations thus have only peripheral effects on behavior. That the internalized rules of behavior are social in origin does not differentiate this argument decisively from a utilitarian one, in which the source of utility functions is left open, leaving room for behavior guided entirely by consensually determined norms and values - as in the oversocialized view" (ibid.). Ou seja, as duas concepções desenraizam os atores do seu contexto social dado. ${ }^{21}$

\section{Granovetter e os economistas modernos}

Voltando-se para os economistas modernos, Granovetter assinala que ao tentarem incorporar em seus esquemas teóricos as influências sociais, eles acabam representando-as de forma sobressocializada. "In so doing, they reverse the judgment that social influences are frictional but sustain the conception of how such influences operate" (1985, p. 57). Utiliza como exemplo a teoria dos mercados de trabalho segmentados de Michael Piore e o estudo de Bowles e Gintis que faz um balanço das conseqüências da educação americana ${ }^{22}$. Conclui, acertadamente, que

${ }_{21}$ Granovetter prossegue e assinala que: "This ironic merger is already visible in Hobbe's Leviathan, in which the unfortunate denizens of the state of nature, overwhelmed by the disorder consequent to their atomization, cheerfully surrender all their rights to an authoritarian power and subsequently behave in a docile and honorable manner; by the artifice of a social contract, they lurch directly from an undersocialized to an oversocialized state" (1992, p. 57).

22 Segundo Granovetter, Piore entende que cada segmento do mercado de trabalho tem um padrão de tomada de decisão. Decisões com base em escolha racional seriam tomadas nos mercados de trabalho primário-superior, decisões por hábito seriam tomadas no primário-inferior e por comando no secundário. E haveria uma correlação entre este padrão de tomada de decisão e a origem de classe- 
estas concepções sobressocializadas da influência das relações sociais sobre o comportamento individual são mecânicas. Basta conhecer a classe social do indivíduo ou seu lugar no mercado de trabalho e sabe-se todo seu comportamento e formas de tomada de decisão. As relações sociais funcionam como uma força externa que condiciona o comportamento dos indivíduos sem provocar outros efeitos. Se soubermos como o indivíduo é afetado pelas relações e estruturas sociais, elas se tornam irrelevantes para a análise. "Social influences are all contained inside an individual's head, so, in actual decision situations, he or she can be atomized as any Homo economicus, though perhaps with different rules for decision" (1992, p. 57).

Tratando do esforço de economistas, como Gary Becker, de considerar as relações sociais em suas análises, Granovetter adverte que eles ignoram o enraizamento histórico e estrutural destas relações, ou seja, não consideram a história destas relações e sua posição frente a outras relações. As descrições fornecidas por estas teorias são de ligações interpessoais estilizadas, convencionais, sem conteúdo, história ou posicionamento estrutural. $\mathrm{O}$ agente atua de acordo com sua posição formal dentro da estrutura social e de acordo com o conjunto de papéis que nela cumpre. Dentro do esquema conceitual geral, este procedimento leva a atribuir um papel menor às relações individuais, com a ênfase recaindo nas estruturas perenes que irão determinar os papéis normativos (1992, p. 57-8). Assim ele conclui que:

In economic models, this treatment of social relations has the paradoxical effect of preserving atomized decision making even when decisions are seen to involve more than one individual. Because the analyzed set of individuals - usually dyads, occasionally larger groups - is abstracted out of social context, it is atomized in its behavior from that of other groups an from the history of its own relations. Atomization has not been eliminated, merely transferred to the dyadic or higher level of analysis. Note the use of an oversocialized conception - that of actors behaving exclusively in accord with prescribed roles - to implement an atomized, undersocialized view (GRANOVETTER, 1992, p. 58).

Novamente aponta para o fato de que as concepções sobressocializadas e subsocializadas convergem para uma visão atomizada do homem. E argumenta que os homens não são como átomos isolados de um dado contexto social, e tão pouco são autômatos dirigidos pelo mecanicismo das relações sociais exógenas a ele. Granovetter arremata, de forma muito apropriada, lembrando que "Their attempts at purposive action are instead embedded in concrete, ongoing systems of social relations" (1992, p. 58). Este é o seu horizonte de pesquisa: os homens realizam ações com teleologia, mas ações enraizadas em relações sociais concretas.

cultura dos trabalhadores (classe média ou operária). Já Bowles e Gintis, ainda segundo Granovetter, entendem que em função do modelo educativo a que têm acesso, as diferentes classes irão desenvolver diferentes padrões cognitivos. Assim, indivíduos que executarão trabalhos menos qualificados, serão treinados para seguir regras e aqueles destinados à posições de elite voltam-se para relacionamentos sociais que se encaixem com os níveis superiores da hierarquia da produção (1992, p. 74). 
Granovetter volta-se em seguida para as questões da confiança e da má-fé, e toma a teoria econômica como espaço para discuti-las. Identifica duas respostas para estas questões, uma fundada na ótica subsocializada do indivíduo (caso da nova economia institucional de Oliver Williamson) e outra na fundada na ótica sobressocializada (vide Kenneth Arrow ou Akerlof). Para a escola da nova economia institucional os arranjos sociais e as instituições são as soluções eficientes para determinados problemas econômicos. A má-fé pode ser evitada por arranjos institucionais que desencorajam a má-fé. Sendo que estes arranjos não produzem confiança, antes a substituem. Os principais tipos de arranjos institucionais seriam os contratos explícitos e implícitos e as estruturas de autoridade que impeçam o oportunismo. Mas por não tratar das relações sociais concretas, não percebem que as obrigações associadas e decorrentes delas desencorajam a má-fé independentemente dos arranjos institucionais. Daí Granovetter dizer que "Substituting these arrangements for trust results actually in a Hobbesian situation, in which any rational individual would be motivated to develop clever ways to evade them; it is then hard to imagine that everyday economic life would not be poisoned by ever more ingenious attempts at deceit” (1992, p. 60).

Os economistas que, ao contrário da nova economia institucional, aceitam que algum grau de confiança tem que existir nas relações sociais devido à incapacidade dos arranjos institucionais impedirem o recurso à força e à fraude, segundo Granovetter, não explicam a origem desta "moral generalizada". Assim, ele aponta nesta corrente a presença de uma visão sobressocializada que aceita a presença de respostas automáticas e generalizadas por parte dos agentes econômicos, “(...) even though moral action in economic life is hardly automatic or universal (...)” (1992, p. 60).

A proposta do enraizamento de Granovetter defende que as redes sociais concretas nas quais os indivíduos estão inseridos estão na origem da confiança e do afastamento da má-fé e do oportunismo. Argumenta que a preferência constatada empiricamente em se negociar com agentes de reputação reconhecida ${ }^{23}$ (cuja informação é obtida junto a outros agentes que negociaram antes com ele) aponta que não há grande eficácia nos arranjos institucionais ou numa "moral generalizada".

Para evitar que o argumento de que as redes sociais vistas como o principal mecanismo de criação de confiança para as relações econômicas caia num novo funcionalismo otimista de manutenção da ordem econômica, Granovetter aponta que: (1) a solução para o problema da ordem dada pela noção de enraizamento não é tão universal quanto as soluções dadas pelas posições alternativas. Pois as redes sociais penetram de forma irregular e em diferentes graus nos vários segmentos da vida econômica, o que abre a possibilidade para desconfiança, oportunismo e desordem. (2) Ainda que as relações e redes sociais sejam condição necessária para a geração de

\footnotetext{
${ }^{23}$ Note que Granovetter não opera com a reputação como uma mercadoria a partir da qual o agente pode calcular as vantagens e desvantagens de enganar outro agente. Ele aponta que tal concepção é subsocializada.
} 
confiança e honestidade, não são condição suficientes e podem inclusive produzir condições e meios para o surgimento de má-fé em proporção superior ao que ocorreria em sua ausência. ${ }^{24}$

Após delinear sua visão de enraizamento enquanto alternativa entre as perspectivas subsocializadas e sobressocializadas, Granovetter passa a crítica da teoria de Oliver Williamson (apresentada em "Markets and Hierarchies" e em outros artigos) enquanto momento de aplicação prática da perspectiva do enraizamento.

Para Williamson uma questão relevante é entender as razões pelas quais certas funções econômicas passam a ser realizadas no interior da grande empresa hierarquizada ao invés de ocorrerem nos mercados com outras empresas fornecedoras. Sua solução recai num tipo de darwinismo que diz que a forma organizacional dominante numa dada situação é a que melhor resolve os problemas ligados aos custos de transação. Assim quando o resultado econômico é muito incerto, quando ocorrem frequentemente, quando envolvem barreiras à saída (investimentos elevados e específicos), o mais provável é que as transações ocorram no interior das empresas organizadas hierarquicamente. Do contrário ocorrem no mercado, entre empresas. Duas razões podem ser listadas para a interiorização das transações pelas empresas hierarquicamente organizadas: $\left(1^{\circ}\right)$ A existência de uma racionalidade limitada, ou seja, a incapacidade dos agentes econômicos anteciparem problemas que possam vir a ocorrer em contratos de longa duração. Se há interiorização das transações, não é preciso fazer tal antecipação e nem realizar complexas transações e custosos contratos. $\left(2^{\circ}\right) \mathrm{O}$ oportunismo é reduzido quando as transações são internalizadas, pois as relações de autoridade e hierarquia, e o relacionamento constante com parceiros de transação no interior da unidade industrial criam novos tipos de constrangimento.

Em relação a esta argumentação, Granovetter posiciona-se assinalando que ela implica na redescoberta de Hobbes aplicado à esfera econômica. Tal análise inclui a mesma mistura de argumentos subsocializados e sobressocializados presentes no "Leviathan".

The efficacy of hierarchical power within the firm is overplayed, as with Hobbe's oversocialized sovereign state. The 'market' resembles Hobbe's state of nature. It is the atomized and anonymous market of classical political economy, minus the discipline brought by fully competitive conditions - an undersocialized conception that neglects the role of social relations among individuals in different firms in bringing order to economic life. (GRANOVETTER, 1992, p. 65)

${ }^{24}$ Granovetter lista três razões para isto: "1. The trust engendered by personal relations presents, by its very existence, enhanced opportunity for malfeasance. (...) 2. Force and fraud are most efficiently pursued by teams, and the structure of these teams requires a level of internal trust 'honor among thieves' - that usually follows preexisting lines of relationship. (...) 3. The extent of disorder resulting from force and fraud depends very much on how the network of social relations is structured. (...)" (1992, p. 62-3) 
Granovetter resume (1992, p. 72-73) de forma breve as diferenças entre as explicações e previsões presentes nas propostas de mercados e hierarquias de Williamson e sua perspectiva de enraizamento. Williamson defende que a internalização das atividades econômicas complexas nas empresas hierarquicamente organizadas é a garantia da inexistência de oportunismo e má-fé e da existência de cooperação e ordem na vida econômica. Mas Granovetter, com base em estudos empíricos, argumenta que mesmo para transações complexas pode-se encontrar ordem no mercado, nas transações entre empresas e um nível alto de desordem no interior da empresa hierarquicamente organizada. E isto se deve à natureza das relações e das redes sociais criadas entre as empresas e no interior das empresas. Logo, para ele ordem e desordem, honestidade e má-fé respondem mais às estruturas das relações e redes sociais do que às formas institucionais. Entretanto, assinala que tal perspectiva traz novas implicações para a compreensão do surgimento da integração vertical no lugar das transações entre empresas via mercado. Supondo situações idênticas, pressões pela integração vertical ocorrerão quando tivermos um mercado no qual falte às empresas uma rede de relações pessoais que as una ou quando tal rede levar a conflitos, oportunismo, desordem e má-fé. Já quando tivermos uma rede de relações pessoais estável, garantindo a ocorrência de transações complexas, com padrões estáveis de comportamento entre as empresas, o mais provável é que não ocorram tais pressões pela integração vertical.

A ideia de utilizar a noção de "pressões", diz Granovetter, é uma tentativa de fugir do funcionalismo implícito na posição teórica de Williamson (a forma organizacional existente é sempre a mais adequada para a situação em questão). Todavia, Granovetter lembra que existem duas condições a serem satisfeitas para que se possa operacionalizar a noção de "pressões": “(i) well-defined and powerful selection pressures toward efficiency must be operating, and (ii) some actor must have the ability and resources to 'solve' the efficiency problem by constructing a vertically integrated firm” (1992, p. 72).

Tomando os dois conceitos principais de Granovetter ("enraizamento" e "construção social da economia”) percebemos que eles são manuseáveis por diferentes correntes teóricas sem que se corrompam. Veja por exemplo, como a crítica de DiMaggio (1994) de que o conceito de "enraizamento" não contêm uma dimensão cultural, é resolvida pelo próprio autor ao propor um novo "enraizamento”, o cultural.

Por fim cabe lembrar a advertência de Granovetter ${ }^{25}$ sobre a necessidade de

25 "Finally, I should add that the level of causal analysis adopted in the embeddedness argument is a rather proximate one. I have had little to say about what broad historical or macrostructural circumstances have led systems to display the social-structural characteristics they have, so I make no claims for this analysis to answer large-scale questions about the nature of modern society or the sources of economic and political change. But the focus on proximate causes is intentional, for these broader questions cannot be satisfactorily addressed without more detailed understanding of the mechanisms by which sweeping change has its effects. My claim is that one of the most important and least analyzed of such mechanisms is the impact of such change on the social relations in which economic life is embedded. If 
estabelecer uma ligação adequada entre os níveis micro e macro de análise a partir de uma compreensão das relações sociais nas quais a vida econômica está enraizada.

\section{Referências}

BECKERT, Jens - Economic Action and Embeddedness: The Problem of the Structure of Action. First Draft, Free University of Berlim, October 1999, 47p.

BLOCK, Fred. Postindustrial Posibilities: A Critique of Economic Discourse. Berkeley-Los Angeles: 1990, 227p.

BOLTANSKI, L.; THÉVENOT, L. - The Sociology of Critical Capacity. European Journal of Social Theory, London: Sage, 2(3), p. 359-377.

COLLINS, Randall - Weber's Last Theory of Capitalism: A Systematization. In. Granovetter, M. and Swedberg, R. (Edit.) The Sociology of Economic Life. Boulder: Westview Press, 1992, p. 85-110.

CORCUFF, Philippe - As Novas Sociologias: Construções da Realidade Social. Bauru: EDUSC, 2001, 206p.

DiMAgGIO, P. - Aspectos Culturais da Acção e da Organização Económica. In. PEIXOTO, J.; MARQUES, R. (org.) - A Nova Sociologia Económica: Uma Antologia. Oeiras: Celta Editora, 2003, p. 167-194.

FLIGSTEIN, N. - O Mercado enquanto Política: Uma Abordagem Político-Cultural às Instituições de Mercado. In. PEIXOTO, J.; MARQUES, R. (org.) - A Nova Sociologia Económica: Uma Antologia. Oeiras: Celta Editora, 2003, p. 195-228.

FLIGSTEIN, N. - States, Markets, and Economic Growth. In. SWEDBERG, R.; NEE, V. - The Economic Sociology of Capitalism. Princeton-New Jersey: Princeton University Press, 2005, p. 119-143.

GIDDENS, Anthony - Política, Sociologia e Teoria Social: Encontros com o Pensamento Social Clássico e Contemporâneo. São Paulo: UNESP, 1998, 336p.

GRANOVETTER, Mark - Economic Institutions as Social Construction: A Framework for Analysis. Mimeo, Paris, 1991, 21p.

this is so, no adequate link between macro- and micro-level theories can be established without a much fuller understanding of these relations" (Granovetter, 1992, 75) 
GRANOVETTER, Mark - The Strengh of Weak Ties. American Journal of Sociology, vol. 78, no. 6, May 1973, p. 1360-1380. Crossef http://dx.doi.org/10.1086/225469

GRANOVETTER, Economic Action na Social Structure: The Problem of Embeddedness. In. GRANOVETTER, Mark and SWEDBERG, Richard (Edit.) The Sociology of Economic Life. Bouder: Westview Press, 1992, p. 53-81.

GRANOVETTER, A Theoretical Agenda for Economic Sociology. In. GUILLEN, Mauro, F., COLLINS, R., ENGLAND, P., and MEYER, M. Economic Sociology at the Millenium, New York: Russel Sage Foundation, 2001.

HIRSCH, P.; MICHAELS, S.; FRIEDMAN, R. - Clean Models vs. Dirty Hands: Why Economics is Different from Sociology. In. In. DIMAGGIO, P.; SHARON, Z. (Ed.) - Structures of Capital: The Social Organization of the Economy. New York: Cambridge, 1990, p. 39-56.

LÖWY, Michael - As Aventuras de Karl Marx contra o Barão de Münchbausen: Marxismo e Positivismo na Sociologia do Conbecimento. São Paulo: Busca Vida, 1987, 210p.

LÖWY, Michael - Método Dialético e Teoria Política. $3^{\mathrm{a}}$. Ed. Rio de Janeiro: Paz e Terra, 1978, 141p.

LÖWY, Michael - Ideologias e Ciências Sociais: Elementos para uma Análise Marxista. $2^{\text {a }}$. Ed., São Paulo: Cortez, 112p.

MARQUES, RAFAEL - Os Trilhos da Nova Sociologia Económica, In. PEIXOTO, J.; MARQUES, R. (org.) - A Nova Sociologia Económica: Uma Antologia. Oeiras: Celta Editora, 2003, p. 1-68.

MURDOCH, Jonathan - Weaving the Seamless Web: A Considration of Network Analysis and its Potential Application to the Study of the Rural Economy. Centre for Rural Economy Working Paper Series, working paper 3, University of Newcastle upon Tyne, February 1994, 27p.

NEE, Victor and INGRAM, Paul - Embeddedness and Beyond: Institutions, Exchange, and Social Structure. In. BRINTON, Mary C. and NEE, Victor (Eds), The New Institutionalism in Sociology. Stanford: Stanford University Press, 1998, p. 19-45.

POLANYI, Karl - A Grande Transformação: As Origens da Nossa Época. Rio de Janeiro: Campus, 2000, 349p.

RAUD-MATTEDI, Cécile - A Construção Social do Mercado em Durkheim e Weber: Análise do Papel das Instituições na Sociologia Econômica Clássica. Revista Brasileira de Ciências Sociais, vol. 20, no. 57, fevereiro de 2005a, p. 127- 142. 
RAUD-MATTEDI, Cécile - Análise crítica da Sociologia Econômica de Mark Granovetter: os limites de uma leitura do mercado em termos de rede e imbricação. Revista Política e Sociedade, no. 6, abril de 2005b, p. 59-82.

STEINER, Philippe - A Sociologia Econômica. São Paulo: Atlas, 2006, 134p.

STEINER, Philippe - Une Historie des Relations entre Économie et Sociologie. L'Économie Politique, 2001/4, no. 12, p. 32-45. <www.cairn.info/article.php?ID REVUE $=$ LECO\&ID NUMPUBLIE $=$ LECO $>$

SWEDBERG, Richard - The Economic Sociology of Capitalism: An Introduction and Agenda. In. SWEDBERG, R.; NEE, V. - The Economic Sociology of Capitalism. Princeton-New Jersey: Princeton University Press, 2005, p. 3 -40.

SWEDBERG, Richard - Max Weber e a Idéia de Sociologia Econômica. Rio de Janeiro: Editora UFRJ; São Paulo: Beca Produções Culturais, 2005b (Col. Economia e Sociedade, v. 5), 384p.

SWEDBERG, Richard - A Nova Sociologia Económica: O que já se atingiu, o que se seguirá? In. PEIXOTO, J.; MARQUES, R. (org.) - A Nova Sociologia Económica: Uma Antologia. Oeiras: Celta Editora, 2003, p. 229-253.

SWEDBERG, Richard - Principles of Economic Sociology. New Jersey: Princeton University Press, 2003, 366p.

SWEDBERG, Richard - Sociologia Econômica: Hoje e Amanhã. Tempo Social, Revista de Sociologia da USP, v. 16, n. 2, 2006, p. 7-34.

SWEDBERG, R.; HIMMELSTRAND, U.; BRULIN, G. - The Paradigm of Economic Sociology. In. DIMAGGIO, P.; SHARON, Z. (Ed.) - Structures of Capital: The Social Organization of the Economy. New York: Cambridge, 1990, p. 57-86.

WEBER, Max - Economia e Sociedade: Fundamentos da Sociologia Compreensiva. $4^{a}$. Ed., Volume 1, Brasília, DF: Editora Universidade de Brasília; São Paulo: Imprensa Oficial do Estado de São Paulo, 1999, 464p.

WEBER, Max - A Ética Protestante e o Espírito do Capitalismo. São Paulo: Companhia das Letras, 2008, 335p. 